\title{
Article \\ Effect of Plasma Nitriding on the Creep and Tensile Properties of the Ti-6Al-4V Alloy
}

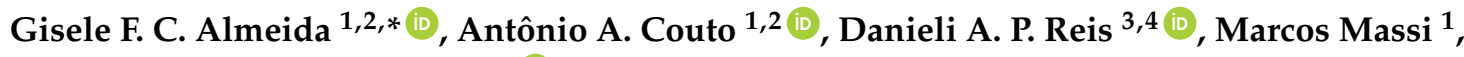 \\ Argemiro S. da Silva Sobrinho ${ }^{4}$ (D) and Nelson B. de Lima ${ }^{2}$ \\ 1 Department of Materials Engineering and Nanotechnology, Universidade Presbiteriana Mackenzie, \\ São Paulo 01302-907, Brazil; acouto@ipen.br (A.A.C.); marcos.massi@mackenzie.br (M.M.) \\ 2 Center for Materials Science and Technology, Instituto de Pesquisas Energéticas e Nucleares, \\ São Paulo 05508-000, Brazil; nblima@ipen.br \\ 3 Science and Technology Department, Universidade Federal de São Paulo-UNIFESP, \\ São José dos Campos 12231-280, Brazil; danielireis@gmail.com \\ 4 Department of Materials and Processes, Instituto Tecnológico de Aeronáutica-ITA/DCTA, \\ São José dos Campos 12228-900, Brazil; argemiro@ita.br \\ * Correspondence: gisele_fab@hotmail.com; Tel.: +55-119-9639-8967
}

Received: 14 July 2018; Accepted: 2 August 2018; Published: 7 August 2018

\begin{abstract}
This work aimed to enhance the creep resistance of Ti-6Al-4V alloy treated by plasma nitriding. The nitriding was performed on specimens with a Widmanstätten microstructure for four hours at $690{ }^{\circ} \mathrm{C}$ under a gas atmosphere containing Ar: $\mathrm{N}_{2}: \mathrm{H}_{2}$ (0.455:0.455:0.090). X-ray diffraction analysis showed that the $\varepsilon-\mathrm{Ti}_{2} \mathrm{~N}$ and $\delta$-TiN formed on the nitrided sample, in addition to the $\alpha$-Ti and $\beta$-Ti matrix phases. The layer thickness of this sample was about $1 \mu \mathrm{m}$. Hot tensile tests were performed in the temperature range of 500 to $700{ }^{\circ} \mathrm{C}$ on nitrided and non-nitrided samples, which indicated an increased strength of the nitrided samples. The same temperature range was used for the creep tests in a stress range of 125 to $319 \mathrm{MPa}$. The plasma-nitrided samples exhibited better creep resistance when compared to the untreated samples. This result was demonstrated by the decreased secondary creep rate and the increased final creep time. This improvement in the creep resistance appeared to be associated with the formation of the nitrided layer, which worked as a barrier to oxygen diffusion into the material and due to the formation of a surface residual compressive stress.
\end{abstract}

Keywords: Ti-6Al-4V; plasma nitriding; hot tensile test; creep

\section{Introduction}

Titanium and its alloys are excellent materials for technological applications, such as structural components that are exposed to elevated temperatures, due to their high strength, low density, good corrosion resistance, and metallurgical stability. The elevated creep resistance of titanium is important for use in engines [1-3]. Titanium is specified for modern gas turbine jet engines, where titanium alloy parts account for 25 to $30 \%$ of the weight, primarily in the compressor. Titanium is the most common material for engine parts that operate up to $593{ }^{\circ} \mathrm{C}\left(1100{ }^{\circ} \mathrm{F}\right)$ [4]. Despite its high melting point, the high solid solubility of oxygen in titanium limits its applications at high temperatures [5]. This limitation is due to the Ti alloys that are suffering from oxidation and environmental embrittlement.

Ti-6Al-4V is the most extensively used titanium alloy because its density is lower than pure titanium and its mechanical and physical properties are better, so it is more suitable for aeronautical applications $[2,6]$. This material has a two-phase microstructure: the hexagonal close-packed (hcp) $\alpha$-Ti 
phase with aluminum in a solid solution, and a $\beta$-Ti phase with vanadium stabilizing the body-centered cubic (bcc) structure. This two-phase structure creates a higher mechanical strength when compared with pure titanium [6,7]. In general, near-alpha alloys have better creep resistance, followed by the $\alpha+\beta$ alloys, and finally, the $\beta$ alloys.

Various types of surface treatments have been investigated [8-14] in order to improve the wear and corrosion resistance of titanium alloys. Among them, plasma nitriding has been shown to be effective [15]. Plasma nitriding has several advantages over other methods, mainly due to the facility of surface depassivation by cathode sputtering, reducing the number of impurities [16,17]. The ability to work efficiently at lower temperatures prevents changes in the microstructure and the mechanical properties of the substrate [18]. The optimal treatment of the entire surface of complex shapes [19], cost efficiency, and performance of parts are also positively affected by the reduced treatment times and the increased hardness of the formed layers $[15,20]$.

The nitriding effect on the near-surface composition of $(\alpha+\beta)-\mathrm{Ti}-6 \mathrm{Al}-4 \mathrm{~V}$ is a complex function of the process parameters. The most significant parameters are temperature, time, gas mixtures, pressure, and electrical parameters [15]. Pure nitrogen, nitrogen-hydrogen, and nitrogen-argon mixtures or a mixture of all these gases in various proportions have been used as the atmosphere for plasma nitriding [21-26]. Although hydrogen can cause embrittlement of titanium alloys, nitrogen-hydrogen plasmas have been frequently used. The purpose of the hydrogen addition in the plasma atmosphere is to capture the oxygen atoms to reduce the impurities [27]. Also, the presence of hydrogen decreases the energy that is required to produce nitrogen atoms via molecular collision dissociation. Since the $\mathrm{H}^{+}$ions have less mass and higher kinetic energy than the $\mathrm{N}^{+}$ions, under the same pressure, voltage, and temperature conditions, reducing the energy required for collision dissociation to produce active $\mathrm{N}$ atoms is possible [28]. The temperature has a significantly greater effect than time on the process [21].

Concerning the creep behavior of the Ti-6Al-4V alloy, the Widmanstätten microstructure was chosen because it has greater creep resistance, which can be attributed to the $\alpha / \beta$ interfaces. These interfaces act as barriers to dislocation motion, and the larger-than-average grain size reduces the grain boundary sliding, dislocation sources, and oxygen rate diffusion along the grain boundaries [29].

The goal of this paper was to perform the plasma nitriding process in Ti-6Al-4V alloy with a Widmanstätten microstructure. The compound layer was analyzed by optical microscope (OM), scanning electron microscope (SEM), and X-ray diffraction (XRD). Additionally, the mechanical behavior was analyzed by hot tensile testing and creep in constant load mode testing.

\section{Materials and Methods}

The titanium alloy Ti-6Al-4V was heat-treated at $1050{ }^{\circ} \mathrm{C}$ for $30 \mathrm{~min}$, and furnace cooled to create the Widmanstätten microstructure. The chemical composition of the main elements (percentage by weight) meets the ASTM B265 requirements [30], as shown in Table 1.

Table 1. Chemical composition of Ti-6Al-4V alloy.

\begin{tabular}{cccccccccc}
\hline Element & Al & V & Fe & O & N & H & C & Total Other & Ti \\
\hline wt $\%$ & $5.5 / 6.75$ & $3.5 / 4.5$ & Max. 0.4 & Max. 0.2 & Max. 0.05 & Max. 0.125 & Max. 0.1 & Max. 0.4 & balance \\
\hline
\end{tabular}

\subsection{Plasma Nitriding Process}

The reactor that was used for plasma nitriding included a cylindrical hermetic chamber developed by the Laboratory of Plasmas and Processes (LPP) of Instituto Tecnológico de Aeronáutica (ITA) with four windows to observe the process. To generate the plasma, the electrodes within the chamber were connected to a direct current (DC) power supply model FCCT 1000-100i (manufactured by Supplier Indústria e Comércio de Eletro-Eletrônicos Ltda., Joinville, Brazil). The output voltage used was between 0 and $1000 \mathrm{~V}$, power $10 \mathrm{~kW}$, and current from 0 to $10 \mathrm{~A}$. A K-type thermocouple (Minipa do Brasil Ltda., São Paulo, Brazil) was attached to the sample holder and connected to 
a digital thermometer (Minipa do Brasil, São Paulo, Brasil) for temperature control inside the chamber. The samples were nitrided for $4 \mathrm{~h}$ at $690^{\circ} \mathrm{C}$. The components of the gas-plasma atmosphere were $45.5 \%$ argon, $45.5 \%$ nitrogen, and a small amount of hydrogen (9\%). The chamber was initially evacuated down to a pressure of about $110 \mathrm{~Pa}$ for one hour to remove the oxygen atmosphere initially present. All of the experiments were performed at a beam current of $0.5 \mathrm{~A}$ and pressure around $400 \mathrm{~Pa}$.

A sample holder developed by LPP (ITA), on which up to 10 samples could be mounted, allowed for the nitriding of all the specimens in a single lot. The sample holder drawing is shown in Figure 1 and a photo of the specimen during the process is shown in Figure 2. The samples were cooled inside the chamber.

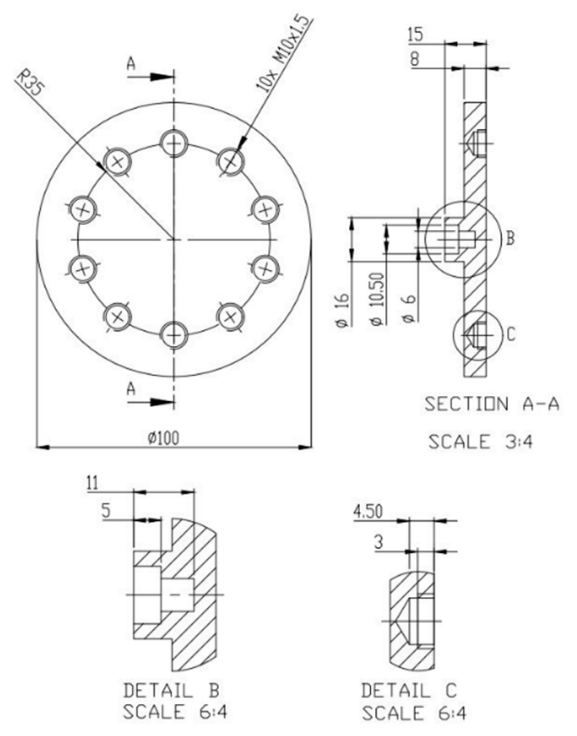

Figure 1. Sample holder drawing used for plasma nitriding.

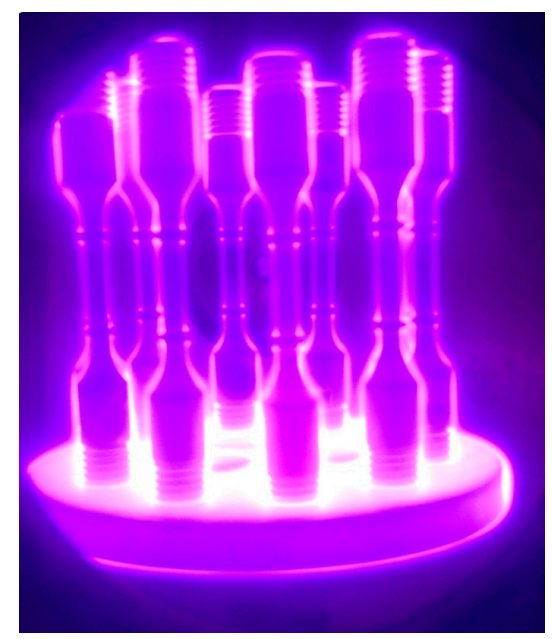

Figure 2. Photographs of creep specimens during plasma nitriding.

\subsection{Hot Tensile Tests}

The tensile tests were performed, according to ASTM E-21-09 [31]. An Instron (São José dos Pinhais, Brazil) model 4400R Universal Testing Instrument coupled to a tube furnace (Instron, São José dos Pinhais, Brazil) with three separate heating zones was used for the tests. The temperature was controlled using two Chromel-Alumel thermocouples (Minipa do Brasil Ltda., São Paulo, Brazil) in contact with the reduced section of the specimen. The tests were performed at 500,600 , and $700{ }^{\circ} \mathrm{C}$, with a crosshead 
speed of $0.5 \mathrm{~mm} / \mathrm{min}$. For each tensile test temperature, tests were performed for both plasma-nitrided and untreated specimens, both with Widmanstätten microstructure.

\subsection{Creep Tests}

The creep tests were performed according to ASTM E-139-11 [32]. The dimensions and shape of the specimen used for the tensile and creep tests are shown in Figure 3. Electrical systems and controllers (Denison Mayes Group, Leeds, UK) were adapted in the furnace (Denison Mayes Group, Leeds, UK). A linear variable differential displacement transducer (LVDT, Denison Mayes Group, Leeds, UK) was used to obtain measures of elongation, and a Cromel-Alumel thermocouple was used to control temperature. The creep tests were performed at 500,600, and $700{ }^{\circ} \mathrm{C}$, and in constant load mode at 125, 250, and $319 \mathrm{MPa}$. The specimens used for the test were heat treated to create the Widmanstätten microstructure and plasma-nitrided. Data from Briguente [33] of the untreated condition were used for comparison.

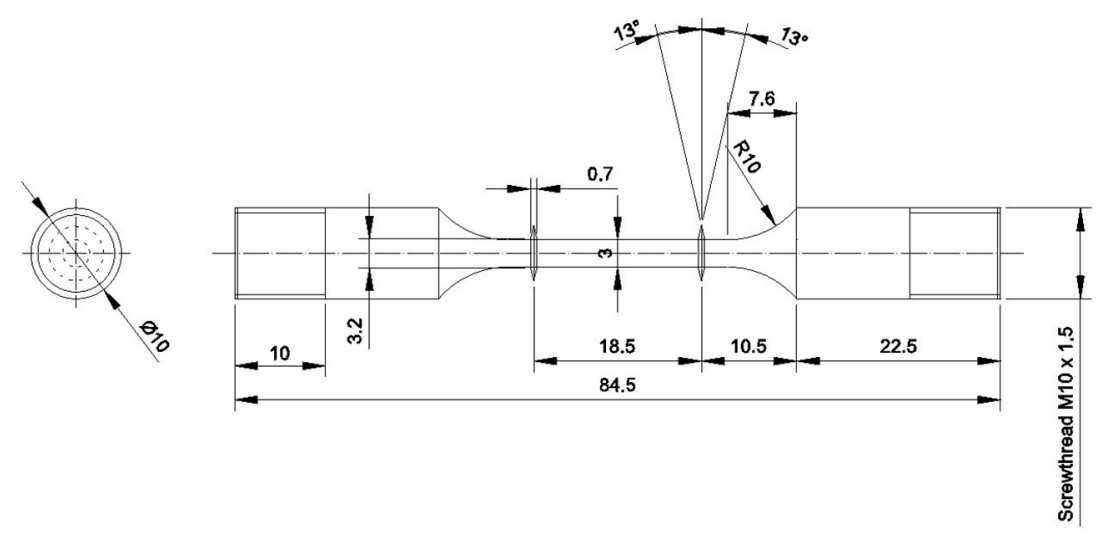

Figure 3. Dimensions ( $\mathrm{mm}$ ) and shape of tensile and creep specimens

\subsection{Characterization}

Metallographic examinations were performed on sample cross-sections after Ti-6Al-4V alloy heat treatment, after the plasma nitriding, and after the mechanical tests. The samples were prepared by a standard grinding procedure using silicon carbide papers and polished with a colloidal silica suspension (OP-S), and subsequently etched with a reagent consisting of $5 \mathrm{~mL} \mathrm{HNO}_{3}$ (conc), $3 \mathrm{~mL} \mathrm{HF}$ $(48 \%)$, and $100 \mathrm{~mL}$ of distilled water. Microstructure observations were performed using an OM (BX60, Olympus, São Paulo, Brazil). Cross sections of the samples were examined by a SEM (XL30, Philips, Eindhoven, The Netherlands) to determine the compound layer thickness. The thickness of the compound layer was predicted by the average of three measurements of five different micrographs. After tests, a fractographic analysis was performed by SEM in order to identify the operating fracture mechanisms by observing the fractures surfaces.

A diffractometer was used for the X-ray diffraction (Multiflex, Rigaku, São Paulo, Brazil) analysis. $X$-ray analysis was operated with $\mathrm{CuK} \alpha$ radiation (wavelength $0.1542 \mathrm{~nm}$ ). The specimens were scanned at $2 \theta$ angles between $20^{\circ}$ and $80^{\circ}$ with a step increment of $0.02^{\circ}$. The resulting XRD peaks were identified while using the Joint Committee on Powder Diffraction Standards (JCPDS) powder index files.

\section{Results and Discussion}

\subsection{Microstructural Characterization}

The different creep resistance results that were found in the literature [29,33-35], due to the various microstructures of Ti-6Al-4V alloy, indicate the need for a heat treatment to homogenize and to 
create the Widmanstätten microstructure prior to nitriding and testing. The optical micrograph of the sample with Widmanstätten microstructure is presented in Figure 4.

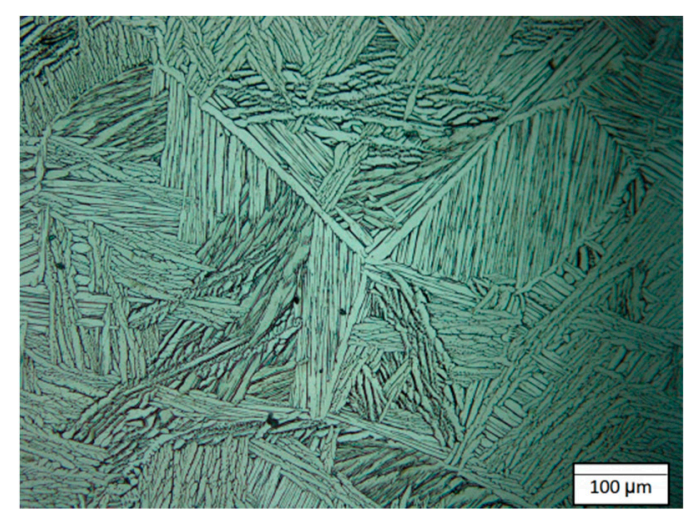

Figure 4. Optical micrograph of the Ti-6Al-4V alloy with Widmanstätten microstructure.

The SEM micrograph of the nitrided sample is shown in Figure 5. The thickness of the nitride layer was estimated to be nearly $1 \mu \mathrm{m}$ in this sample. In the nitrided layer, only one present phase (darker gray) could be identified, which can be explained because nitrogen is an alpha phase stabilizing element that may have caused a wrapping to form a continuous layer (called an alpha casing) [2]. According to Rajasekaran and Morita [36,37], the formation of this nitride surface layer generated a surface residual compressive stress that helped to increase the creep resistance. This layer formation may also act as a barrier to oxygen diffusion into the material, contributing to the increase in creep resistance [10,38]. As reported by Pérez [38], for titanium and its alloys, the nitride layer reduces the contribution of oxygen dissolution in the substrate to the total mass gain. The better oxidation resistance of Ti nitrides when compared with the $\alpha$-Ti is due to the strong interaction between titanium and nitrogen, which decreases the thermodynamic activity of titanium.

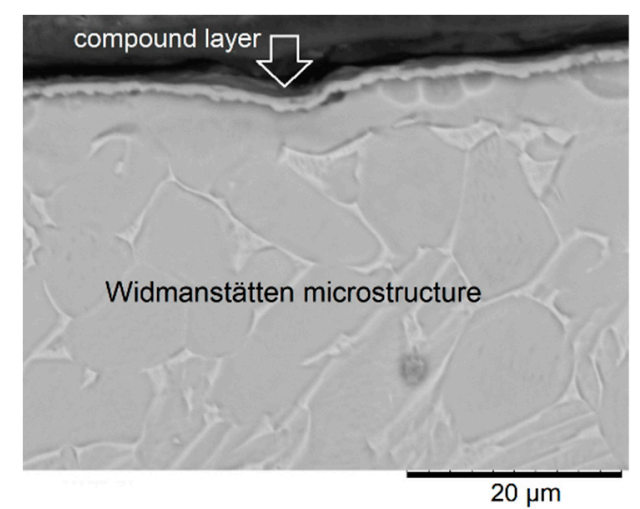

Figure 5. Scanning electron microscopy (SEM) micrograph of plasma-nitrided Ti-6Al-4V with Widmanstätten microstructure.

No significant changes were observed in the microstructure after plasma nitriding. The optical micrographs of the specimens after the heat treatment and after the plasma nitriding and creep test are presented in Figure 6. 


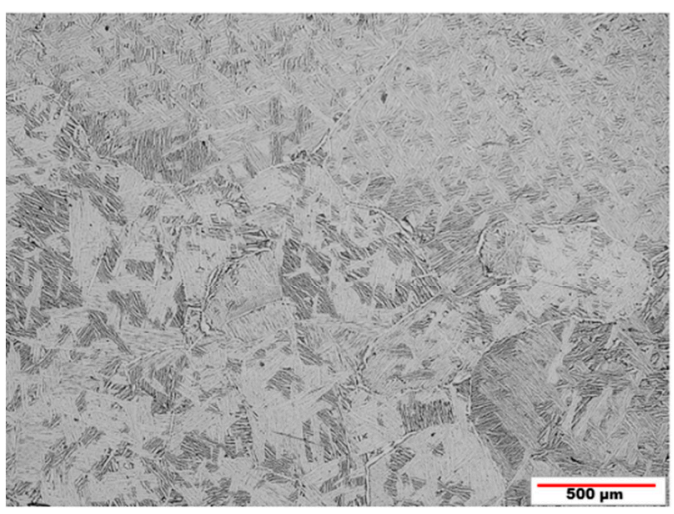

(a)

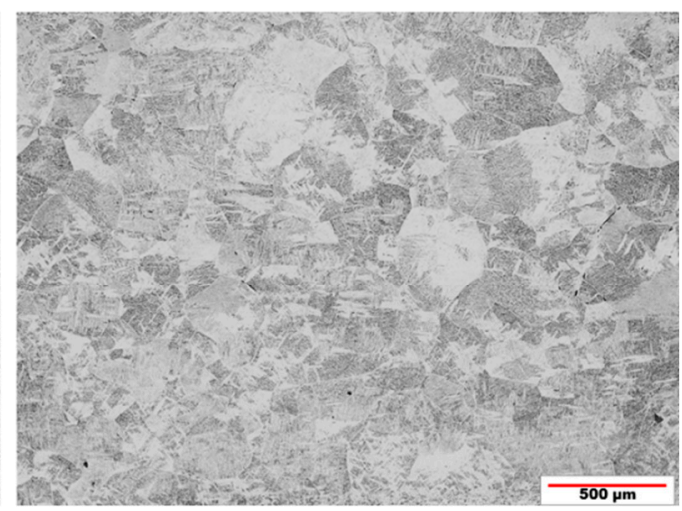

(b)

Figure 6. Optical micrograph of the Ti-6Al-4V alloy with Widmanstätten microstructure: (a) after the heat treatment and (b) after the plasma nitriding and creep test.

The XRD analysis performed on the as-received sample is presented in Figure 7 . The diffraction pattern was fitted with $\alpha$-Ti (JCPDS file 44-1294) and the $\beta$-Ti (JCPDS file 44-1288) phases, the same as was identified by other authors $[19,22,25,39,40]$.

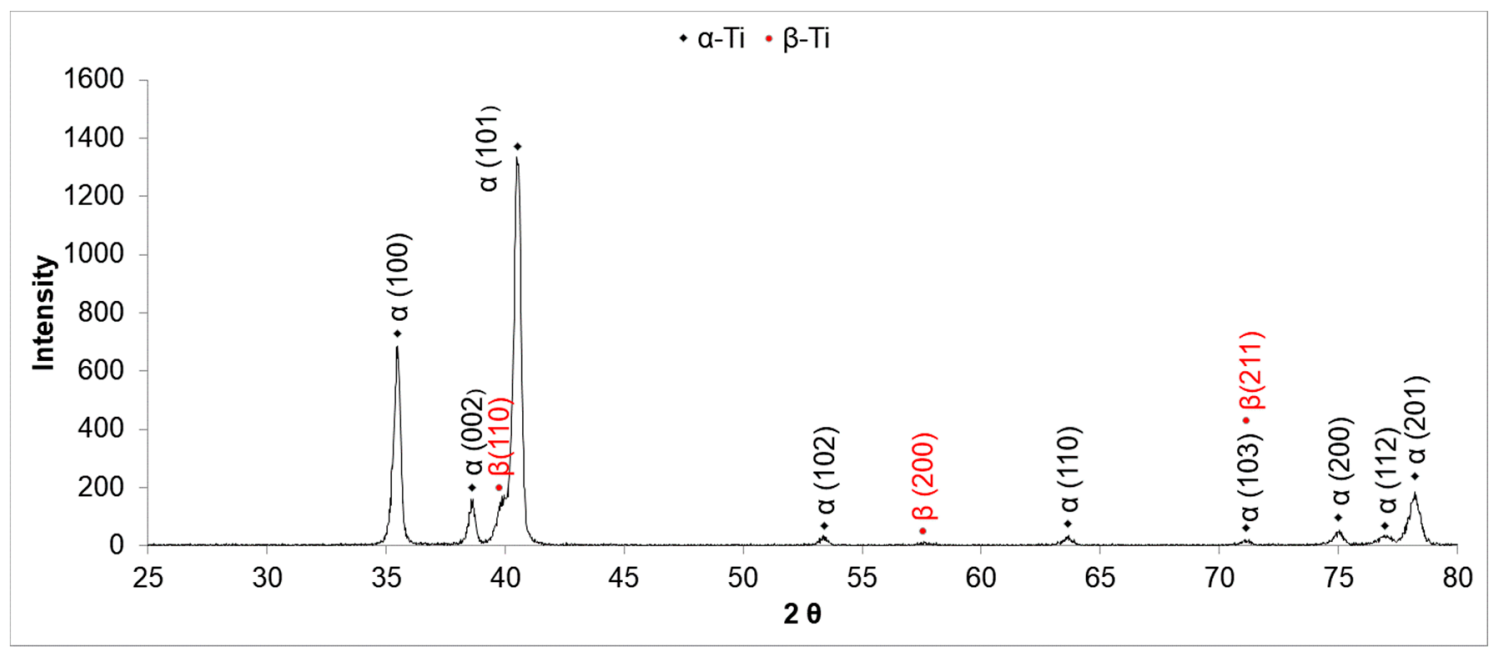

Figure 7. X-ray diffraction (XRD) pattern of the untreated Ti-6Al-4V sample.

The XRD analysis that was performed on the plasma-nitrided sample is presented in Figure 8. The analysis confirmed the presence of the face-centered cubic $\delta$-TiN (JCPDS file 38-1420) and the tetragonal $\varepsilon-\mathrm{Ti}_{2} \mathrm{~N}$ (JCPDS file 17-0386) $[19,22,39,41,42]$. Also, the $\alpha$-Ti phase was present, which was the same one that was found in the as-received sample. Rahman et al. [25] also observed the (111) and (200) diffraction planes of nitrogen-rich $\delta$-TiN phase at temperatures above $700{ }^{\circ} \mathrm{C}$. In this pattern, identifying the presence of the $\beta$-Ti phase using XRD was difficult when the $\alpha$-Ti phase was also present. The most intense reflection of the $\beta$-Ti phase (110) was in a coincident position to a reflection of $\alpha$-Ti phase (002), thus masking the result. As the amount of $\beta$-Ti phase in the alloy was relatively small and as the lower intensity of the other reflections did not coincide, it was practically impossible to ensure the presence of the $\beta$-Ti phase while using only XRD analysis [43]. 


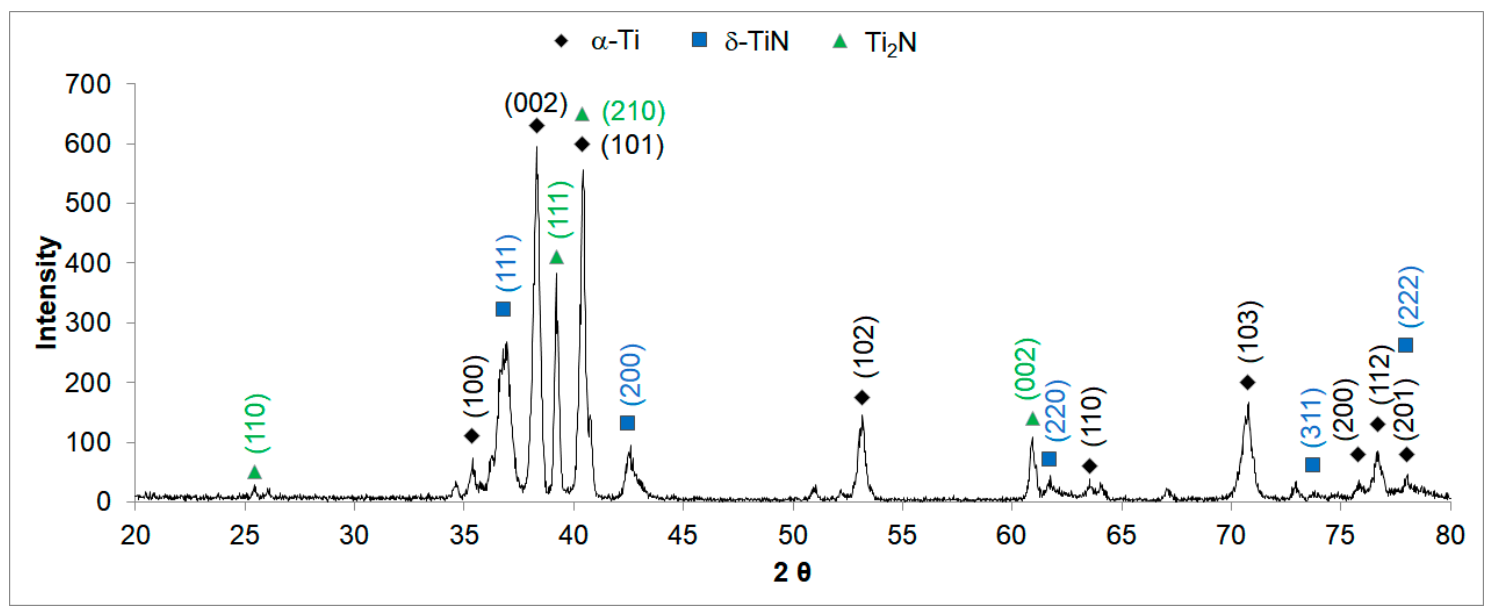

Figure 8. XRD pattern of plasma-nitrided Ti-6Al-4V alloy.

\subsection{Tensile and Creep Tests}

The plasma-nitrided Ti-6Al-4V alloy specimens with Widmanstätten microstructure were used in the tensile and creep tests. The tensile properties of the untreated Ti-6Al-4V and plasma-nitrided alloy are summarized in Table 2, including $0.2 \%$ yield stress (YS), ultimate tensile stress (UTS), elongation (EL), and reduction of area (RA). The YS and UTS increased significantly for the nitrided condition. The increase in YS ranged from $56 \mathrm{MPa}$ for the test that was performed at $700{ }^{\circ} \mathrm{C}$, to $154 \mathrm{MPa}$ at $500{ }^{\circ} \mathrm{C}$, which represent gains of 20 and $29 \%$, respectively. For UTS, the increases ranged from 68 $\mathrm{MPa}$ for the test performed at $700{ }^{\circ} \mathrm{C}$ to $165 \mathrm{MPa}$ at $500{ }^{\circ} \mathrm{C}$, which represent gains of 23 and $29 \%$, respectively. The EL and RA results did not clearly indicate an effect due to nitriding.

Table 2. Tensile data obtained from tensile tests on untreated and plasma-nitrided Ti-6Al-4V alloy.

\begin{tabular}{cccccc}
\hline Temperature $\left({ }^{\circ} \mathbf{C}\right)$ & Condition & YS (MPa) & UTS (MPa) & EL (\%) & RA (\%) \\
\hline \multirow{2}{*}{500} & untreated & 525 & 576 & 8 & 23.3 \\
& plasma-nitrided & 679 & 741 & 8 & 40.4 \\
\hline \multirow{2}{*}{600} & untreated & 419 & 434 & 9 & 26.9 \\
& plasma-nitrided & 532 & 587 & 10 & 22.5 \\
\hline \multirow{2}{*}{700} & untreated & 281 & 302 & 14 & 51.8 \\
& plasma-nitrided & 337 & 370 & 16 & 49.0 \\
\hline
\end{tabular}

The results of the short-term creep tests performed under constant load are summarized in Table 3. Results of the creep tests, as obtained from the Ti-6Al-4V alloy without surface treatment (untreated), were compared with data from Briguente [33] under the same test conditions and microstructure reported in the literature. The primary creep time $(t p)$, secondary creep rate $\left(\dot{\varepsilon}_{s}\right)$, final creep time $(t f)$, and final strain $\left(\varepsilon_{f}\right)$ are presented in Table 3 . The plasma-nitrided alloy showed higher creep resistance with a longer creep time and lower steady-state creep rate in all of the tests that were performed. The tp also increased in the condition at $600{ }^{\circ} \mathrm{C}$ and $250 \mathrm{MPa}$. 
Table 3. Creep data of the plasma-nitrided Ti-6Al-4V with Widmanstätten microstructure to untreated condition, data from Briguente [33].

\begin{tabular}{|c|c|c|c|c|c|c|}
\hline Temperature $\left({ }^{\circ} \mathrm{C}\right)$ & $\sigma(\mathbf{M P a})$ & Condition & $t p(\mathrm{~h})$ & $\dot{\varepsilon}_{s}(1 / \mathrm{h})$ & $t f(\mathrm{~h})$ & $\varepsilon_{f}(\mathrm{~mm} / \mathrm{mm})$ \\
\hline \multirow[b]{2}{*}{500} & \multirow[b]{2}{*}{319} & untreated $^{1}$ & 16.000 & 0.00035 & 224.00 & 0.112 \\
\hline & & plasma-nitrided & 8.300 & 0.00008 & 251.27 & 0.038 \\
\hline \multirow{6}{*}{600} & \multirow{2}{*}{125} & untreated $^{1}$ & 9.000 & 0.00140 & 102.12 & 0.286 \\
\hline & & plasma-nitrided & 4.000 & 0.00038 & 112.56 & 0.464 \\
\hline & \multirow{2}{*}{250} & untreated $^{1}$ & 0.350 & 0.03040 & 2.03 & 0.098 \\
\hline & & plasma-nitrided & 0.417 & 0.00367 & 6.03 & 0.031 \\
\hline & \multirow{2}{*}{319} & untreated $^{1}$ & 0.067 & 0.16000 & 0.62 & 0.237 \\
\hline & & plasma-nitrided & 0.042 & 0.02070 & 1.17 & 0.056 \\
\hline \multirow{2}{*}{700} & \multirow{2}{*}{319} & untreated $^{1}$ & 0.003 & 7.54000 & 0.01 & 0.158 \\
\hline & & plasma-nitrided & 0.008 & 1.08000 & 0.02 & 0.022 \\
\hline
\end{tabular}

${ }^{1}$ Untreated condition data were taken from Briguente's study [33].

The reduction in the steady-state creep rate, which indicates a slower creep rate, demonstrated the higher creep resistance of plasma-nitrided Ti-6Al-4V samples. This is due to the hardened superficial layer formed in Ti-6Al-4V alloy by the plasma nitriding. A hard superficial layer and interstitial solid solutions increase the creep resistance of some alloys. The hardened superficial increases rupture life in the creep tests [44].

A final creep time comparison is shown in Table 4. The nitrided samples had higher creep resistance than the surface of the untreated samples. The effect of the nitrided layer seems to be more effective in creep life at a temperature of $600{ }^{\circ} \mathrm{C}$. This can be justified by the fact that $700{ }^{\circ} \mathrm{C}$ is a very severe temperature for titanium, and its degradation is much greater at this temperature. In relation to the stress conditions that were investigated, $250 \mathrm{MPa}$ was more suitable because it is a moderate stress when compared with $319 \mathrm{MPa}$ and the high temperature exposure time of the film was less than at $125 \mathrm{MPa}$. This is related to the film stability during the exposure time at this temperature and stress that is required to maintain the increase of the substrate mechanical resistance. Investigations that are related to film stability have not been approached and will be addressed in future works.

Table 4. Comparison of the final creep time $(t f)$ for the untreated condition in relation to plasma-nitrided.

\begin{tabular}{ccc}
\hline Temperature $\left({ }^{\circ} \mathbf{C}\right)$ & $\sigma$ (MPa) & Relation \\
\hline 500 & 319 & 1.12 \\
\hline \multirow{2}{*}{600} & 125 & 1.10 \\
& 250 & 2.97 \\
700 & 319 & 1.90 \\
\hline
\end{tabular}

The creep curve obtained at $500{ }^{\circ} \mathrm{C}$ and $319 \mathrm{MPa}$, corresponding to true strain $\varepsilon$ as a function of the time $t$, is shown in Figure 9. A longer time in creep and lower steady-state creep rate were achieved in the plasma-nitrided condition. 


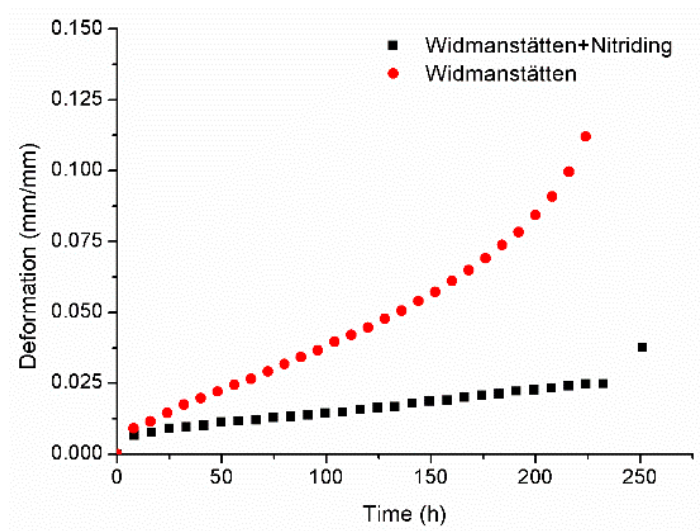

Figure 9. Creep curves of the plasma-nitrided Ti-6Al-4V alloy at $500{ }^{\circ} \mathrm{C}$ and $319 \mathrm{MPa}$ with Widmanstätten microstructure as compared to data from Briguente [33] at untreated condition.

The logarithmic relationship between steady creep rates and stress is shown in Figure 10. Using standard regression techniques, the value of the stress dependence of the steady-state creep rate (n) can be described in terms of power-law creep equations [45]:

$$
\dot{\varepsilon_{s}}=B \sigma^{n}
$$

where $B$ is the structure-dependent constant and $\sigma$ is the applied stress.

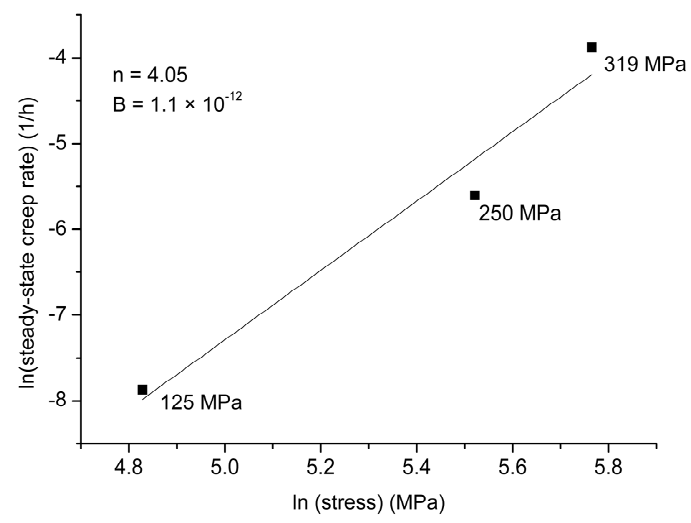

Figure 10. Steady-state creep rate dependence with the stress applied at $600{ }^{\circ} \mathrm{C}$ of the plasma-nitrided Ti-6Al-4V alloy.

The logarithmic relationship between steady creep rates and inverted absolute temperature at $319 \mathrm{MPa}$ is shown in Figure 11. The temperature dependence of the creep rate is normally well represented by an Arrhenius equation. By standard regression techniques, the values of the activation energy $(Q c)$ can be described in terms of the Arrhenius's Law [45]:

$$
\dot{\varepsilon_{s}}=B_{0} \sigma^{n} \exp \left(-Q_{c} / R T\right)
$$

where $B_{0}$ is the structure-dependent constant, $\sigma$ is the applied stress, $R$ is the gas constant, and $T$ is the temperature that is applied.

According to Evans and Wilshire [45], the values of the activation energy for creep $(Q c)$ that is found closer to the activation energy for lattice self-diffusion (QSD) and $n$ values were larger than three. Temperatures between 40 to $70 \%$ of the melting point, under intermediate or high stress levels, help to predict that the dominant mechanism is dislocation creep. The activation energy of self-diffusion reported for $\alpha$-Ti is in the range of 242 to $293 \mathrm{~kJ} / \mathrm{mol}$ [46]. In high-purity $\alpha$-Ti, activation energies of 
303 and $329 \mathrm{~kJ} / \mathrm{mol}$ were found for Ti-self diffusion and Al solute diffusion, respectively. This increase in the value is justified due to the amount and the nature of impurities. Fast diffusing impurities Fe, $\mathrm{Ni}$, and Co had several effects on Ti self-diffusion [47].

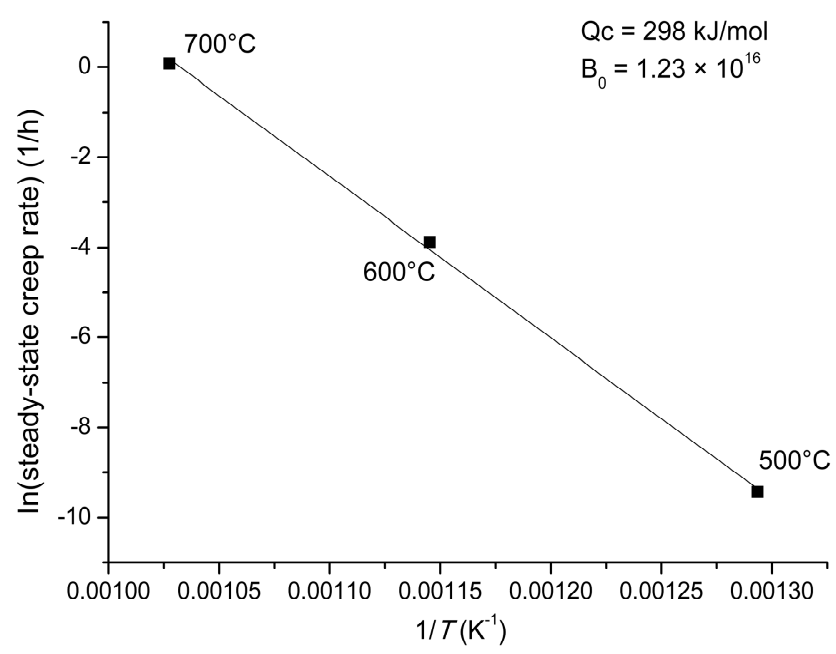

Figure 11. The diagram to determine the activation energy (Qc) at $319 \mathrm{MPa}$ of the plasma-nitrided Ti-6Al-4V alloy.

The value found for the $Q_{c}$ and $n$ obtained for the plasma-nitrided sample were consistent with a dislocation creep mechanism. Thus, the creep mechanism in the Ti-6Al-4V alloy is dominated by a dislocation mechanism that is similar to many pure metals and solid solution alloys when tested at approximately $0.5 \mathrm{Tm}$ [48]. Warren et al. [48] and Harrigan [49] reported that the activation energy of creep $Q_{c}$ is $240.0 \mathrm{~kJ} / \mathrm{mol}$ and that the stress exponent $n$ is 3.4 and 3.8 in Ti-6Al-4V for secondary creep in the temperature range of 600 to $680^{\circ} \mathrm{C}$.

The values of the stress exponent from secondary creep $(n)$ and activation energy $(Q c)$ that were found in the literature for the Ti-6Al-4V alloy are summarized in Table 5. The values found for the nitrided material are in good agreement with those previously reported [9,33,35,50-53]. In general, the values obtained for the stress exponent $n$ increased when the creep resistance of the material increased. However, this parameter does not infer the increase in the resistance of the material to creep, which can only be measured by the steady flow rate.

Table 5. Values of the stress exponent from secondary creep $(n)$ and activation energy $(Q c)$ for Ti-6Al-4V alloy.

\begin{tabular}{cccc}
\hline Reference & Condition & $n$ & $Q c(\mathbf{k J} / \mathbf{m o l})$ \\
\hline$[50]$ & Equiaxed grain & 4.12 & 319 \\
{$[52]$} & Equiaxed grain & 3.59 & 266 \\
{$[35]$} & Equiaxed grain + plasma immersion ion implantation (PIII) & 3.23 & 282 \\
{$[53]$} & Equiaxed grain + laser nitrided & 6.46 & 261 \\
{$[9]$} & Widmanstätten + plasma carburized & 5.64 & 277 \\
{$[33]$} & Widmanstätten & 4.91 & 314 \\
{$[35]$} & Widmanstätten + plasma immersion ion implantation (PIII) & 5.12 & 301 \\
This work & Widmanstätten plasma-nitrided & 4.00 & 298 \\
\hline
\end{tabular}

The Monkman-Grant relationship is described as:

$$
t_{f}\left(\dot{\varepsilon}_{s}\right)^{M}=C
$$


where $M$ and $C$ are the constants. The parameter $M$ corresponds to a measurement of the influence of the secondary creep rate on the creep rupture time. In general, $M$ values are found around the unit for various materials, indicating the proportionality between the rupture time and the rate of deformation in the secondary stage, as proposed by Monkman and Grant [54]. The $C$ value may be related to the ductility of the material. In general, low $C$ values are associated with low creep ductility. Figure 12 shows the correlation between time to fracture and steady-state creep rate under untreated and plasma-nitrided conditions.

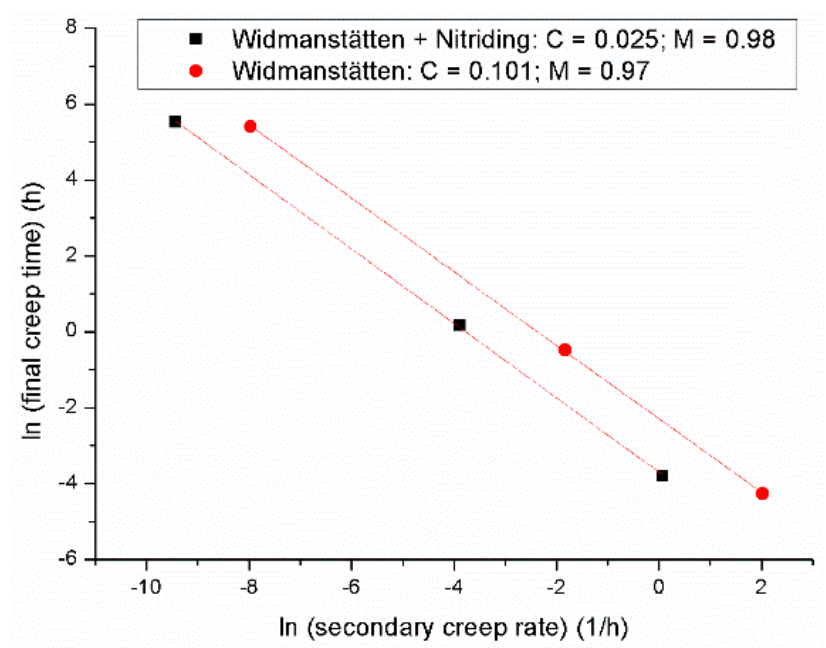

Figure 12. Secondary creep rate dependence for the applied stress of $319 \mathrm{MPa}$ to plasma-nitrided Widmanstätten microstructure alloy as compared to data from Briguente [33] for untreated alloy.

The lower $C$ value that was found for the plasma-nitrided alloy suggests a reduction in ductility, which is confirmed by the $\varepsilon_{f}$ values that are shown in Table 3. A value of $M$ near one indicates that all conditions follow the same relationship, which means that all processes involve the glide and climb of dislocations. The values of $M$ and $C$ reported in the literature for the Ti-6Al-4V alloy are summarized in Table 6 to compare the results to this work.

Table 6. Values of the constants $M$ and $C$ for the Monkman-Grant relationship.

\begin{tabular}{cccc}
\hline References & Condition & \multicolumn{1}{c}{$\boldsymbol{M}$} \\
\hline This work & Widmanstätten microstructure (plasma-nitrided) & 0.979 & 0.025 \\
{$[55]$} & Equiaxed grain microstructure (untreated and laser nitrided) & 0.933 & 0.069 \\
{$[33]$} & Bimodal, martensitic and Widmanstätten microstructure (uncoated, and thermal barrier coating) & 1.047 & 0.082 \\
{$[50]$} & Equiaxed grain microstructure (tested in air atmosphere) & 1.090 & 0.085 \\
{$[51]$} & Equiaxed grain microstructure (tested in air and nitrogen atmosphere) & 1.102 & 0.092 \\
{$[33]$} & Widmanstätten microstructure (untreated) & 0.968 & 0.101 \\
{$[35]$} & Equiaxed grain, Widmanstätten and martensitic microstructure (plasma immersion ion implantation (PIII) treated) & 0.919 & 0.125 \\
{$[52]$} & Equiaxed grain microstructure (uncoated, metallic coating, and thermal barrier coating) & 0.967 & 0.150 \\
\hline
\end{tabular}

\subsection{Fractographic Analysis}

SEM fractographs that were obtained from the Ti-6Al-4V alloy creep tested at $600{ }^{\circ} \mathrm{C}$ and $125 \mathrm{MPa}$ are displayed in Figure 13. The appearance of the fracture surface was ductile with the presence of the dimples, which is a typical alveolar structure based on microvoid coalescence. This result aligns with those that were reported for the same material with different surface treatments by other authors [35,56-58].

Spherical dimples are characteristic of ductile fracture resulting from uniaxial tensile loads. The coalescence of microvoids leads to a gradual and continuous rupture, forming a cup-and-cone fracture. The irregular and fibrous appearance of the fractured surface indicates plastic deformation $[59,60]$. 
SEM fractographs that were obtained from the Ti-6Al-4V alloy creep tested at $700{ }^{\circ} \mathrm{C}$, and $319 \mathrm{MPa}$ are displayed in Figure 14. This parabolic shape indicates shear failure. The region that is circled in red shows the formation of slip lines [60]. The presence of these slip lines shows the ease with which the dislocations by-pass microstructural barriers by changing slip planes due to the higher temperature.

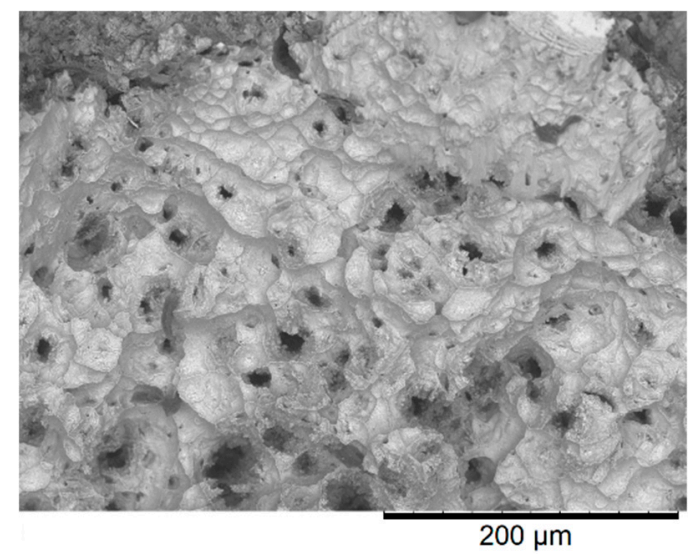

Figure 13. SEM micrograph of the fracture surface of the Widmanstätten plasma-nitrided Ti-6Al-4V alloy after creep test at $600{ }^{\circ} \mathrm{C}$ and $125 \mathrm{MPa}$.

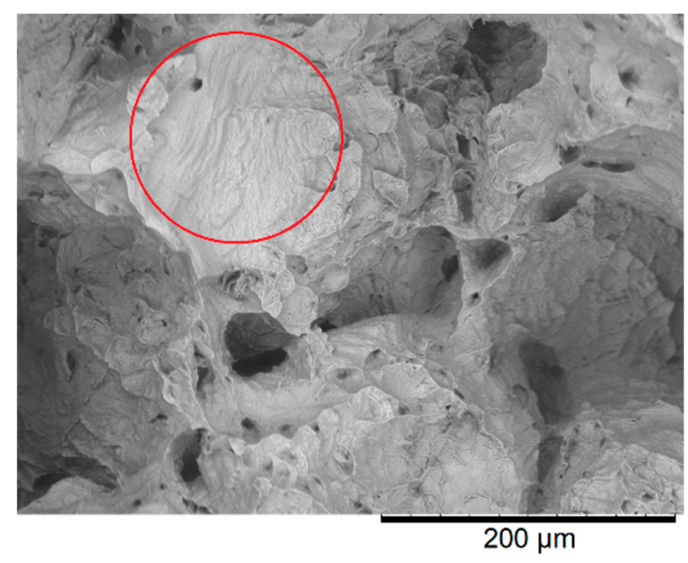

Figure 14. SEM micrograph of the fracture surface of Widmanstätten plasma-nitrided Ti-6Al-4V alloy after creep test at $700{ }^{\circ} \mathrm{C}$ and $319 \mathrm{MPa}$.

\section{Conclusions}

Our study of the effect of plasma nitriding on the creep and tensile properties of the Ti-6Al-4V alloy with Widmanstätten microstructure allowed for us to draw the following conclusions.

In the nitrided layer of about $1 \mu \mathrm{m}$, formed in the plasma-nitrided samples, the presence of $\varepsilon-\mathrm{Ti}_{2} \mathrm{~N}$ and $\delta$-TiN compounds was confirmed. The $\varepsilon$-Ti phase was also found in the as-received sample. Hot tensile tests indicated an increase in the strength of the nitrided alloy. The results of the creep tests showed an increase in creep resistance when compared with untreated specimens. This was evidenced both by the decreased secondary creep rate and the increased final creep time. Increasing the primary creep time also indicated an improvement in creep resistance of the plasma-nitrided specimen with the Widmanstätten microstructure. This improvement of the creep resistance seems to be associated with the formation of the nitrided layer, which could work as a barrier to oxygen diffusion into the material, and due to the formation of a surface residual compressive stress. The range of activation energy fits quite well with titanium self-diffusion values, confirming the role of dislocation climb during creep. Additionally, the steady-state creep rate and the rupture time are related by the Monkman-Grant 
relation with an $M$ value of about one, which means that all of the processes involve the glide and climb of dislocations.

Consequently, we inferred that the plasma nitriding of Ti-6Al-4V can be helpful in applications at elevated temperatures during long-term use due to the improvement in the creep resistance. As most components in aerospace applications are used in extreme operating conditions with high stress and high temperatures, this discovery is attractive for these kinds of applications.

Author Contributions: Conceptualization: G.F.C.A., A.A.C., D.A.P.R., M.M. and A.S.d.S.S.; Validation: G.F.C.A., A.A.C., D.A.P.R., M.M., A.S.d.S.S., and N.B.L.; Formal Analysis: G.F.C.A., D.A.P.R. and N.B.d.L.; Investigation: G.F.C.A., D.A.P.R., M.M., A.S.d.S.S., and N.B.d.L.; Writing-Review and Editing: G.F.C.A. and A.A.C.; Supervision: A.A.C.

Funding: This research received no external funding.

Conflicts of Interest: The authors declare no conflict of interest.

\section{References}

1. Chowdhury, M.; Chowdhury, S.; Yamamoto, K.; Beake, B.; Bose, B.; Elfizy, A.; Cavelli, D.; Dosbaeva, G.; Aramesh, M.; Fox-Rabinovich, G.; et al. Wear behaviour of coated carbide tools during machining of Ti6Al4V aerospace alloy associated with strong built up edge formation. Surf. Coat. Technol. 2017, 313, 319-327. [CrossRef]

2. Banerjee, D.; Williams, J.C. Perspectives on titanium science and technology. Acta Mater. 2013, 61, 844-879. [CrossRef]

3. Ochonogor, O.F.; Akinlabi, E.T.; Nyembwe, D. A review on the effect of creep and microstructural change under elevated temperature of Ti6Al4V alloy for turbine engine application. Mater. Today Proc. 2017, 4, 250-256. [CrossRef]

4. International Titanium Association Titanium-The Infinite Choice. Available online: http:/ /c.ymcdn.com/ sites/www.titanium.org/resource/resmgr/Docs/TiUltimate.pdf (accessed on 23 July 2014).

5. Souza, M.L.R.; Fernandes, B.B.; Mändl, S.; Oliveira, R.M.; Ueda, M.; Ramos, A.S. Effects of plasma immersion ion implantation on fatigue properties of titanium alloy surfaces. Rev. Bras. Apl. Vácuo 2018, 36, 131. [CrossRef]

6. Antunes, R.A.; Salvador, C.A.F.; Oliveira, M.C.L. Materials Selection of Optimized Titanium Alloys for Aircraft Applications. Mater. Res. 2018. [CrossRef]

7. Berberich, F.; Matz, W.; Richter, E.; Schell, N.; Kreißig, U.; Möller, W. Structural mechanisms of the mechanical degradation of Ti-Al-V alloys: In situ study during annealing. Surf. Coat. Technol. 2000, 128-129, 450-454. [CrossRef]

8. Sugahara, T.; Martins, G.V.; Montoro, F.E.; Merij Neto, A.; Massi, M.; Silva Sobrinho, A.S.; Reis, D.A.P. Creep behavior evaluation and characterization of $\mathrm{SiC}$ film with $\mathrm{Cr}$ interlayer deposited by HiPIMS in Ti-6Al-4V alloy. Surf. Coat. Technol. 2017, 309, 410-416. [CrossRef]

9. Oliveira, V.M.C.A.; da Silva, M.C.L.; Pinto, C.G.; Suzuki, P.A.; Machado, J.P.B.; Chad, V.M.; Barboza, M.J.R. Short-term creep properties of Ti-6Al-4V alloy subjected to surface plasma carburizing process. J. Mater. Res. Technol. 2015, 4, 359-366. [CrossRef]

10. Oliveira, A.C.; Oliveira, R.M.; Reis, D.A.P.; Carreri, F.C. Effect of nitrogen high temperature plasma based ion implantation on the creep behavior of Ti-6Al-4V alloy. Appl. Surf. Sci. 2014, 311, 239-244. [CrossRef]

11. Ahmed, S.; Chakrabarty, D.; Bhowmik, S.; Mukherjee, S.; Rane, R. Plasma nitriding on titanium surface for adhesion promotion. Surf. Eng. 2015, 31, 616-622. [CrossRef]

12. Almeida, G.F.C.; Couto, A.A.; Reis, D.A.P.; Massi, M.; Silva, A.S.; Lima, N.B. Estudo da Nitretação por Plasma na Fluência da Liga Ti-6Al-4V. Tecnol. Metal. Mater. Min. 2016, 13, 331-339. [CrossRef]

13. Lee, D.B.; Abro, W.A.; Lee, K.S.; Abro, M.A.; Pohrelyuk, I.; Yaskiv, O. Gas Nitriding and Oxidation of Ti-6Al-4V Alloy. Defect Diffus. Forum 2018, 382, 155-159. [CrossRef]

14. Severino, B.P.; Couto, A.A.; Reis, D.A.P.; Aguiar, C.L.; Castagnet, M.; Moura Neto, C. Study of high temperature mechanical behavior of the thermally oxidized Ti-6Al-4V alloy. Materialwiss. Werkstofftech. 2014, 45, 269-280. [CrossRef] 
15. Zhecheva, A.; Sha, W.; Malinov, S.; Long, A. Enhancing the microstructure and properties of titanium alloys through nitriding and other surface engineering methods. Surf. Coat. Technol. 2005, 200, $2192-2207$. [CrossRef]

16. Roliński, E. Surface properties of plasma-nitrided titanium alloys. Mater. Sci. Eng. A 1989, 108, 37-44. [CrossRef]

17. Rolinski, E.; Sharp, G.; Cowgill, D.F.; Peterman, D.J. Ion nitriding of titanium alpha plus beta alloy for fusion reactor applications. J. Nucl. Mater. 1998, 252, 200-208. [CrossRef]

18. Ali, M.M.; Raman, S.G.S.; Pathak, S.D.; Gnanamoorthy, R. Influence of plasma nitriding on fretting wear behaviour of Ti-6Al-4V. Tribol. Int. 2010, 43, 152-160. [CrossRef]

19. Fouquet, V.; Pichon, L.; Drouet, M.; Straboni, A. Plasma assisted nitridation of Ti-6Al-4V. Appl. Surf. Sci. 2004, 221, 248-258. [CrossRef]

20. Farè, S.; Lecis, N.; Vedani, M.; Silipigni, A.; Favoino, P. Properties of nitrided layers formed during plasma nitriding of commercially pure Ti and Ti-6Al-4V alloy. Surf. Coat. Technol. 2012, 206, 2287-2292. [CrossRef]

21. Hosseini, S.R.; Ahmadi, A. Evaluation of the effects of plasma nitriding temperature and time on the characterisation of Ti 6Al 4V alloy. Vacuum 2013, 87, 30-39. [CrossRef]

22. Vasconcellos, M.A.Z.; Lima, S.C.; Hinrichs, R. Hardness evaluation, stoichiometry and grain size of titanium nitride films obtained with plasma nitriding on Ti-6Al-4V samples. Mater. Braz. 2010, 15, 299-302. [CrossRef]

23. Raaif, M.; El-Hossary, F.M.; Negm, N.Z.; Khalil, S.M.; Schaaf, P. Surface treatment of Ti-6Al-4V alloy by rf plasma nitriding. J. Phys. Condens. Matter 2007, 19, 396003. [CrossRef]

24. Pohrelyuk, I.M.; Tkachuk, O.V.; Proskurnyak, R.V. Corrosion Behaviour of Ti-6Al-4V Alloy with Nitride Coatings in Simulated Body Fluids at $36^{\circ} \mathrm{C}$ and $40^{\circ} \mathrm{C}$. ISRN Corros. 2013, 2013, 241830. [CrossRef]

25. Rahman, M.; Reid, I.; Duggan, P.; Dowling, D.P.; Hughes, G.; Hashmi, M.S.J. Structural and tribological properties of the plasma nitrided Ti-alloy biomaterials: Influence of the treatment temperature. Surf. Coat. Technol. 2007, 201, 4865-4872. [CrossRef]

26. Tang, J.; Liu, D.; Tang, C.; Zhang, X. Surface modification of Ti-6Al-4V alloy by cathode assisting discharge setup and conventional plasma nitriding methods. Sci. China Technol. Sci. 2013, 56, 1858-1864. [CrossRef]

27. Michel, H.; Czerwiec, T.; Gantois, M. Progress in the analysis of the mechanisms of ion nitriding. Surf. Coat. Technol. 1995, 72, 103-111. [CrossRef]

28. Bingzhong, X.; Yingzhi, Z. Collision Dissociation Model in Ion Nitriding. Surf. Eng. 1987, 3, $226-232$. [CrossRef]

29. Sugahara, T.; Reis, D.A.P.; Moura Neto, C.; Barboza, M.J.R.; Perez, E.A.C.; Piorino Neto, F.; Hirschmann, A.C.O. The Effect of Widmanstätten and Equiaxed Microstructures of Ti-6Al-4V on the Oxidation Rate and Creep Behavior. Mater. Sci. Forum 2010, 636-637, 657-662. [CrossRef]

30. American Society for Testing and Materials (ASTM). ASTM B265-15: Standard Specification for Titanium and Titanium Alloy Strip, Sheet, and Plate; ASTM International: West Conshohocken, PA, USA, 2015.

31. American Society for Testing and Materials (ASTM). ASTM E21-09: Standard Test Methods for Elevated Temperature Tension Tests of Metallic Materials; ASTM International: West Conshohocken, PA, USA, 2009.

32. American Society for Testing and Materials (ASTM). ASTM E139-11: Standard Test Methods for Conducting Creep, Creep Rupture, and Stress Rupture Tests of Metallic Materials; ASTM International: West Conshohocken, PA, USA, 2011.

33. Briguente, L.A.N.S. Estudo de Tratamento Térmico e Recobrimento Como FORMA de barreira Térmica Sobre o Comportamento em Fluência da Liga Ti-6Al-4V. Master's Thesis, Instituto Tecnológico de Aeronaútica, São José dos Campos, Brazil, May 2011. (In Portuguese)

34. Yogi, L.M.; Sugahara, T. Efeito do Tratamento Térmico na Fluência da Liga Ti-6Al-4V. Rev. Bras. Apl. Vácuo 2008, 27, 189-194. (In Portuguese)

35. Yogi, L.M. Estudo da Fluência da Liga Ti-6Al-4V após Tratamento Térmico e Implantação Iônica por Imersão em Plasma. Master's Thesis, Instituto Tecnológico de Aeronáutica, São José dos Campos, Brazil, October 2012. (In Portuguese)

36. Rajasekaran, B.; Raman, S.G.S. Plain fatigue and fretting fatigue behaviour of plasma nitrided Ti-6Al-4V. Mater. Lett. 2008, 62, 2473-2475. [CrossRef]

37. Morita, T.; Asakura, K.; Kagaya, C. Effect of combination treatment on wear resistance and strength of Ti-6Al-4V alloy. Mater. Sci. Eng. A 2014, 618, 438-446. [CrossRef] 
38. Pérez, P. Influence of nitriding on the oxidation behaviour of titanium alloys at $700{ }^{\circ} \mathrm{C}$. Surf. Coat. Technol. 2005, 191, 293-302. [CrossRef]

39. Fernandes, A.C.; Vaz, F.; Ariza, E.; Rocha, L.A.; Ribeiro, A.R.L.; Vieira, A.C.; Rivière, J.P.; Pichon, L. Tribocorrosion behaviour of plasma nitrided and plasma nitrided+oxidised Ti6Al4V alloy. Surf. Coat. Technol. 2006, 200, 6218-6224. [CrossRef]

40. Da Silva, S.L.R.; Kerber, L.O.; Amaral, L.; Dos Santos, C.A. X-ray diffraction measurements of plasma-nitrided Ti-6Al-4V. Surf. Coat. Technol. 1999, 116-119, 342-346. [CrossRef]

41. Molarius, J.M. Ti-N phases formed by reactive ion plating. J. Vac. Sci. Technol. A Vac. Surf. Film 1985, 3, $2419-2425$. [CrossRef]

42. She, D.; Yue, W.; Fu, Z.; Wang, C.; Yang, X.; Liu, J. Effects of nitriding temperature on microstructures and vacuum tribological properties of plasma-nitrided titanium. Surf. Coat. Technol. 2015, 264, 32-40. [CrossRef]

43. Couto, A.A.; Faldini, S.B.; Almeida, G.F.C.; Sekeres, T.S.; Kunioshi, C.T.; Morcelli, A.E.; Lima, N.B. Caracterização microestrutural da liga Ti-6Al-4V comercial utilizada como biomaterial. In Proceedings of the $17^{\circ}$ CBECIMat, Foz do Iguaçu, Brazil, 15-19 November 2006; pp. 4365-4376. (In Portuguese)

44. Rosen, A.; Rottem, A. The effect of high temperature exposure on the creep resistance of Ti-6Al-4V alloy. Mater. Sci. Eng. 1976, 22, 23-29. [CrossRef]

45. Evans, R.W.; Wilshire, B. Introduction to Creep; The Institute of Materials: London, UK, 1993.

46. Palehan, I.; Rosen, A. History dependent creep of Ti-6Al-4V alloy. Met. Sci. 1978, 12, 163-165. [CrossRef]

47. Köppers, M.; Herzig, C.; Friesel, M.; Mishin, Y. Intrinsic self-diffusion and substitutional Al diffusion in $\alpha$-Ti. Acta Mater. 1997, 45, 4181-4191. [CrossRef]

48. Warren, J.; Hsiung, L.M.; Wadley, H.N.G. High temperature deformation behavior of physical vapor deposited Ti-6Al-4V. Acta Metall. Mater. 1995, 43, 2773-2787. [CrossRef]

49. Harrigan, W.C. Creep fracture characteristics of weld-repaired cast Ti-6Al-4V. Metall. Trans. 1974, 5, 565-572. [CrossRef]

50. Barboza, M.J.R.; Moura Neto, C.; Silva, C.R.M. Creep mechanisms and physical modeling for Ti-6Al-4V. Mater. Sci. Eng. A 2004, 369, 201-209. [CrossRef]

51. Reis, D.A.P. Efeito do Recobrimento Cerâmico e da Atmosfera de Ensaio na Fluência de Liga Metálica Refratária de Titânio. Ph.D. Thesis, Instituto Nacional de Pesquisas Espaciais, São José dos Campos, Brazil, September 2005. (In Portuguese)

52. Briguente, F.P.; Briguente, L.A.N.S.; Reis, D.A.P.; Da Silva, M.M. Comparative Study of Creep Resistance of a Ti-6Al-4V Alloy with Metallic and Ceramic Coatings. Mater. Sci. Forum 2014, 802, 472-476. [CrossRef]

53. Reis, A.G.; Reis, D.A.P.; Moura Neto, C.; Barboza, M.J.R.; Oñoro, J. Creep behavior and surface characterization of a laser surface nitrided Ti-6Al-4V alloy. Mater. Sci. Eng. A 2013, 577, 48-53. [CrossRef]

54. Monkman, F.C.; Grant, N.J. An empirical relationship between rupture life and minimum creep rate in creep-rupture tests. ASTM Proc. 1956, 56, 91-103.

55. Reis, A.G.; REIS, D.A.P.; Moura Neto, C.; Barboza, M.J.R.; Piorino Neto, F.; Oñoro, J. Creep behavior study at $500^{\circ} \mathrm{C}$ of laser nitrided Ti-6Al-4V alloy. J. Mater. Res. Technol. 2013, 2, 48-51. [CrossRef]

56. Sugahara, T.; Moura Neto, C.; Reis, D.A.P.; Piorino Neto, F. Caracterização Mecânica e Microestrutural da Liga Ti-6Al-4V Tratada Termicamente. Rev. Bras. Apl. Vácuo 2008, 27, 195-199. (In Portuguese)

57. Freitas, F.E.; Silva, M.M.; Sugahara, T.; Reis, D.A.P.; Moura Neto, C.; Ueda, M. Efeito do Tratamento de Implantação Iônica por Imersão em Plasma nas Propriedades da Liga Ti-6Al-4V à Altas Temperaturas. Rev. Bras. Apl. Vácuo 2010, 28, 55-58. (In Portuguese)

58. Briguente, L.A.N.S.; Briguente, F.P.; Reis, D.A.P.; Moura Neto, C.; Resende, F.A. Avaliação do Comportamento em fluência da liga Ti-6Al-4V com Estrutura Martensítica e Equiaxial a $600^{\circ} \mathrm{C}$. Tecnol. Metal. Mater. Min. 2013, 10, 324-328. [CrossRef]

59. Van Stone, R.H.; Cox, T.B.; Low, J.R.; Psioda, J.A. Microstructural aspects of fracture by dimpled rupture. Int. Met. Rev. 1985, 30, 157-180. [CrossRef]

60. ASM International, v. 12 Fractography. In ASM Handbook; ASM International: Novelty, OH, USA, 1987; p. 857, ISBN 9780871700186.

(C) 2018 by the authors. Licensee MDPI, Basel, Switzerland. This article is an open access article distributed under the terms and conditions of the Creative Commons Attribution (CC BY) license (http:/ / creativecommons.org/licenses/by/4.0/). 